Forthcoming in Nous

\title{
$\underline{\text { Democracy as a Modally Demanding Value }}^{1}$
}

\author{
NICHOLAS SOUTHWOOD
}

Australian National University

\section{The Problem of Hands-Off Imperialism}

Suppose that a powerful and aggressive polity, Pugnatia, successfully invades and occupies a weaker and peace-loving polity, Pacifistia, with the twin aim of appropriating Pacifistia's valuable natural resources and securing certain strategic objectives. Pacifistia is now part of Pugnatia's empire, and the highest authority in Pacifistia is the president of Pugnatia. Pugnatia extracts Pacifistia's uranium and maintains a substantial military presence in Pacifistia. If the Pacifistians engage in resistance, they are subject to retaliation. Yet, despite this, life in Pacifistia under occupation is very similar to life before. The Pugnatians are prepared to allow the Pacifistians to continue to elect governments and run their domestic affairs as they see fit, so long as the government doesn't try to interfere with Pugnatia's pursuit of its economic and military objectives. Pugnatia doesn't impose or enforce its harsh laws on the Pacifistians but, rather, allows the elected government to create, interpret, and enforce its own, rather nicer laws.

The case of Pacifistia raises a puzzle. It is natural to suppose that imperialism is deeply antithetical to democracy. ${ }^{2}$ Yet this seems hard to square

\footnotetext{
${ }^{1}$ Earlier versions of this paper were presented at the Democracy, Empires and Geopolitics Conference at the Center for Political Thought, Academia Sinica, Taipei; and in the Centre for Moral, Social and Political Theory Seminar Series in the School of Philosophy, Australian National University. I am very grateful to many people for their helpful feedback on those and other occasions. I would particularly like to thank Arash Abizadeh, Christian Barry, Chia-Ming Chen, Stephanie Collins, Hugh Doherty, John Filling, Al Hajek, Jon Herington, Holly Lawford-Smith, Seth Lazar, David Miller, Philip Pettit, Leif Wenar, Dave Wiens, and Lea Ypi.
} 
with what happens in Pacifistia. Imperialism involves the ongoing occupation and at least partial control of one polity by another polity. ${ }^{3}$ But, as the case of Pacifistia brings out, imperialism may take two importantly different forms. ${ }^{4}$ First, there is what we can call "hands-on imperialism." Imperialism is hands-on, in the relevant sense, when the imperial power takes over the business of governing the occupied polity. Second, there is what we can call "hands-off imperialism," where the imperial power allows the occupied polity to continue to govern itself. ${ }^{5}$ Democracy is certainly undermined by hands-on imperialism, since the latter involves the replacement of governance of the polity by the people with governance of the polity by an external agent. But democracy and hands-off imperialism might seem to be perfectly compatible. Democracy is commonly thought to be a matter of collective self-governance; and hands-off imperialism doesn't undermine collective self-governance, since, by definition, it involves a form of occupation in which the occupied polity is allowed to continue to govern itself. To be sure, as a matter of fact, imperialism is rarely - if ever completely hands-off. Moreover, we may have other compelling reasons to object to imperial rule, whether hands-on or hands-off: it presumably violates rights of

\footnotetext{
${ }^{2}$ Notice that we are concerned here with the question of whether a polity may engage in imperial conquest without undermining the democratic status of the occupied polity, not the (also important) question of whether a democratic polity may engage in imperial conquest without undermining its own status as a democracy.

${ }^{3}$ Cf. Sidney Morgenbesser, "Imperialism: Some Preliminary Distinctions," Philosophy \& Public Affairs, 3 (1973): 3-44, pp. 11-12.

${ }^{4}$ I am grateful to Ole Koksvik for suggesting these labels.

${ }^{5}$ Historically, many empires have deployed both hands-on and hands-off kinds of imperialism at different stages (see Simon Price and Peter Thonemonn, The Birth of Classical Europe: A History from Troy to Augustine (London; New York: Allen Lane, 2010)). For example, during the first two hundred years of Roman rule, from the reign of Augustus (27BC-14AD) to Septimus Severus (193-211AD), the Romans generally practiced a relatively hands-off form of imperialism. This was possible, in part, because of their remarkable success in exporting the ideal of Rome. Civic communities across the Mediterranean and European world (with the exception of the Jews and the Britons) wanted to be Roman; and the empire was constructed from a relatively consensual desire to share in both the profits and prestige. After the reign of Severus, and until the collapse of the empire in the West, the empire became far more hands-on; and this, in effect, spelt the end. Many thanks to Hugh Doherty for illuminating discussion.
} 
the citizens of the occupied polity, such as territorial occupation and use rights. ${ }^{6}$ But, at least in principle, and so far as democracy is concerned, it may seem that we needn't reject hands-off imperialism.

I shall argue that the solution to the puzzle is to recognize that democracy requires more than self-governance. Rather, it requires what I shall call self-rule. Self-rule is an example of what, following Philip Pettit, I shall call a modally demanding value. ${ }^{7}$ Modally demanding values are, roughly, values the instantiation of which depends not only on what actually happens but also on what would happen in certain non-actual circumstances. Self-rule is the modally demanding counterpart of self-governance. In other words, it requires, not merely that the citizens of the polity actually govern themselves, but that they would continue to govern themselves across a range of non-actual situations. Moreover, the value of democracy is not reducible to the value of selfgovernance. The upshot is that democratic polities have reason to object to imperialism even if the imperial power will, as a matter of fact, allow them to continue to govern themselves.

I shall begin by very briefly considering and rejecting three prima facie appealing alternative attempts to explain what is democratically objectionable about imperialism: first, that imperialism makes it more likely that selfgovernance will be undermined; second, that imperialism makes self-governance practically impossible; and third, that imperialism involves the violation of rights

\footnotetext{
${ }^{6}$ For an argument that empires that meet certain moral standards are no harder to justify than states, see Christopher Morris, "What's Wrong With Imperialism?" Social Philosophy \& Policy, 23 (2006): 153-66.

7 The notion of a modally demanding value is articulated and explored by Pettit, for example, in "Freedom and Probability: A Comment on Goodin and Jackson," Philosophy \& Public Affairs, 36 (2008): 206-20; "The Instability of Freedom as Non-Interference: the Case of Isaiah Berlin," Ethics, 121 (2011): 693-716; and Making Good: 2011 Oxford Uehiro Lectures in Ethics (Oxford: oxford University Press, forthcoming).
} 
that are part of part of democracy, interpreted in a "thick" sense (section II). I shall then introduce the category of modally demanding values in general (section III), explain and defend the claim that democracy is a modally demanding value (section IV), and show how this helps to explain the incompatibility of democracy and imperialism (section V).

\section{The Democratic Case Against Hands-Off Imperialism: Three Unsatisfactory} $\underline{\text { Accounts }}$

\section{A. The Increased Probability Account}

It might be argued that the democratic case against hands-off imperialism is simply that the occupation and control of one polity by another polity necessarily increases the probability that self-governance, and hence democracy itself, will be compromised or undermined. Imperial powers that are initially happy to wield hands-off power will often subsequently be motivated to take on a more direct role in the governance of the occupied polity, in order to facilitate the pursuit of their national interests. Moreover, hands-off imperialism is presumably not in general a stable equilibrium. The citizens of occupied polities will often resent occupation by a foreign power and engage in organized forms of resistance, which in turn will often encourage the imperial power to retaliate by retracting the initial concessions and directly taking on the governance of the occupied polity. So, there is a slippery slope from hands-off to more hands-on forms of imperialism. As democrats, we should resist getting onto the slope in the first place. This is what is democratically objectionable about hands-off imperialism. Call this "the Increased Probability Account." 
Suppose, however, that Pacifistia happens to be encircled by a number of belligerent states, of which Pugnatia is the most benign. The nastiest of all is Fascistia. If Pugnatia doesn't invade Pacifistia, then it is very likely that Fascistia will do so instead. And it is virtually certain that, if Fascistia invades Pacifistia, Pacifistia will be subjected to hands-on, rather than hands-off, imperial rule. So, in fact, Pugnatia's invasion of Pacifistia lowers the probability that selfgovernance in Pacifistia will be compromised or undermined. To be sure, there is some probability that Pugnatia's hands-off imperial rule will morph into handson imperial rule and hence that self-governance in Pacifistia will be undermined. But this remains lower than the probability that self-governance in Pacifistia will be undermined if Pugnatia does not subject Pacifistia to hands-off imperial rule, since, in that case, it is very likely that Fascistia will subject Pacifistia to hands-on imperial rule. ${ }^{8}$ The Increased Probability Account therefore fails to condemn, and hence lacks application to, Pugnatia's hands-off imperial rule of Pacifistia, since, in this case, it does not raise (but lowers) the probability that selfgovernance in Pacifistia will be compromised or undermined. ${ }^{9}$

\footnotetext{
8 Perhaps it is possible to construct more sophisticated versions of the Increased Probability Account, based on complex conditional probabilities, that are not susceptible to this objection. I shall not consider such accounts here.

${ }^{9}$ Furthermore, the Increased Probability Account seems to be based on a normative claim that is at least questionable, namely, the claim that taking seriously the value of democracy means that we should condemn any event that raises the probability that democracy will be compromised or undermined. Consider an analogy. Suppose that two friends face the choice of whether to go travelling together. Suppose, moreover, that their going travelling together raises the probability that the friendship will be compromised or undermined. A safer bet would be to remain at home. Does this mean that taking seriously the value of friendship requires that they refrain from going travelling together? Not obviously. On the contrary, it is at least arguable that what valuing a valuable friendship really requires is being open to circumstances that have the potential to take the friendship to the next level, even when these risk compromising the friendship such as it is. In any case, it is far from obvious that it rules out such openness. Similarly, it is at least arguable that taking seriously the value of democracy requires, or at least does not rule out, being open to circumstances that will potentially take the democracy to the next level, even when these raise the probability that democracy will be compromised or undermined, such as certain kinds of (probably destabilizing) participatory reforms.
} 


\section{B. The Practical Impossibility Account}

A second argument is that hands-off imperialism makes it practically impossible for the occupied polity to govern itself. Even in its hands-off guise imperialism involves occupation and some degree of control over the occupied polity. Presumably this will be a source of resentment to the citizens of the occupied polity and run counter to the will of the occupied people. Thus, if democratic institutions are working in such a way that they reflect the will of the people, then we should expect the government of the polity to take steps to resist the imperial power. On the other hand, such resistance is clearly not a genuine practical possibility. As we have seen, even a hands-off imperial power must be disposed to repudiate behavior that challenges its occupation and control of the occupied polity, either by rendering ineffective attempts at resistance, or by sanctioning those who resist, or perhaps even by becoming more hands-on. Thus, hands-off imperialism in effect makes it practically impossible for the occupied polity to govern itself. ${ }^{10}$ Call this "the Practical Impossibility Account."

But it needn't be true that hands-off imperialism makes self-governance practically impossible, since it needn't be true that hands-off imperialism is contrary to the will of the people. ${ }^{11}$ Return again to Pacifistia. There are at least two ways in which the citizens of Pacifistia might become reconciled to hands-off imperial power. First, occupation of Pacifistia by Pugnatia might turn out to make the citizens of Pacifistia considerably better off. Perhaps Pugnatia invests

\footnotetext{
${ }^{10} \mathrm{I}$ am assuming that self-governance, in order to be meaningful, involves being in a position to execute the decisions that are made.

11 Moreover, it does not follow from the fact that hands-off imperial rule is contrary to the will of an occupied people that the people's will is to resist the imperial power. It may be that the people are realistic. While they deeply resent being under occupation, they also realize that resistance will be futile, and that it will be likely to make everyone worse off. Hence they don't wish the government to take steps to resist the imperial power. If this is so, then it seems that the government would not be contravening the will of the people by refraining from doing so.
} 
heavily in infrastructure, albeit for its own selfish reasons. Perhaps Pugnatia

provides jobs for Pacifistian locals, who previously had few prospects of gainful

employment. Perhaps occupation by Pugnatia drastically reduces the likelihood

of occupation by Fascistia, a prospect that has haunted Pacifistian parents for

generations. Second, the Pacifistians might become reconciled to occupation by

Pugnatia as a result of some kind of false consciousness. They may come to

regard their partially subjugated status as superior to one in which they possess

complete freedom. Worse, they may come to regard themselves as innately

inferior, and hence to believe that occupation by Pugnatia is nothing more than

they deserve. Under these circumstances, hands-off imperialism needn't make

self-governance in Pacifistia practically impossible. ${ }^{12}$

\section{The Rights Account}

Finally, it might be argued that hands-off imperialism involves the violation of rights that are part of part of democracy, interpreted in a "thick" sense. Selfgovernance may be enough for a polity to count as "democratic" in a "narrow" or "thin" sense. But, at least in principle, a polity might govern itself in ways that, say, systematically disregarded the rights of its citizens to express their views

\footnotetext{
12 It might be said that self-governance is meaningful only insofar as the people have control over the territory and its resources - in effect, that there is a territory that is "theirs to govern." Since even hands-off imperialism involves some degree of control over the occupied territory, it follows that meaningful self-governance is necessarily compromised to some degree by imperialism. One problem with this argument is that even if meaningful self-governance requires a "domain of jurisdiction," it doesn't follow the domain of jurisdiction must be territorial. (For a fascinating discussion of the relation between jurisdiction and territory, see Anne Orford, "Jurisdiction Without Territory: From the Holy Roman Empire to the Responsibility to Protect," Michigan Journal of International Law, 30 (2009): 981-1015.) But even if it does require a territory, it is not obvious that it requires control over that territory. It is surely enough that the polity be in a position to actively make use of, and make decisions involving, the territory. Moreover, control of a territory surely needn't rule out others actively making use of, and making decisions regarding, that territory. If this is right, imperialism isn't incompatible with meaningful self-governance simply in virtue of involving control over an occupied territory. I am very grateful to David Miller and Leif Wenar for discussion of these issues.
} 
without fear of reprisal, or to associate in the ways they see fit; perhaps such draconian policies reflect the will of the people. It is at least arguable that there is something democratically deficient about such a polity. Insofar as democracy is something we have reason to care about, it might seem that it should be interpreted "thickly" such that a democratic polity must also involve respect for certain civil rights, such as freedom of expression and freedom of association. ${ }^{13}$ Perhaps the democratic objection to hands-off imperialism is that it involves the violation of these rights. Call this "the Rights Account."

Perhaps imperial powers will necessarily violate some of the rights of the citizens of occupied polities, for example, certain territorial rights. As we said, imperialism involves the occupation and at least partial control of the territory of another polity, and hence will plausibly contravene the individual and collective rights of the citizens of the occupied polity to occupy and use the territory as they see fit. ${ }^{14}$ Moreover, imperial powers will clearly often violate the particular rights that are required in order for a polity to count as democratic in a thick sense, such as freedom of expression and association. To allow citizens of the occupied polity to freely express their views (say, views that are hostile to the imperial power) and associate with one another (say, in organized resistance groups) will often result in activities that threaten the control of the imperial power.

The question is whether imperial powers will necessarily violate the particular rights that are required in order for a polity to count as democratic.

\footnotetext{
13 See e.g. Richard Vernon, Political Morality: A Theory of Liberal Democracy (New York: Continuum, 2001);

14 See Tamar Meisels, Territorial Rights (Dordrecht: Springer, 2009); Anna Stilz, "Why Do States Have Territorial Rights?" International Theory, 1 (2), 2009: 185-213; David Miller, "Territorial Rights: Concept and Justification," Political Studies, forthcoming.
} 
Suppose that Pugnatia has become so powerful that it recognizes that it needn't worry about whether the Pacifistians express views that are hostile to Pugnatia, or form organized resistance groups. Pugnatia is perfectly happy to allow a vibrant civil society to flourish, for the Pacifistians to write impassioned letters and deliver speeches denouncing Pugnatia's occupation of Pacifistia, even for the Pacifistians to take to the streets and stridently protest the occupation. Surely, under these circumstances it cannot be denied that Pugnatia is fully respecting the rights of the Pacifistians to freedom of speech and association. To be sure, Pugnatia may not be respecting other rights of the Pacifistians, such as their right to occupy and use the Pacifistian territory as they see fit. But such rights cannot plausibly be considered to be among the rights that must be respected in order for a polity to count as democratic. There are limits to how "thick" our conception of democracy may become.

I have very briefly considered, and suggested reasons to be skeptical about, three attempts to explain what is democratically objectionable about hands-off imperialism. If we think that there is necessarily something democratically wrong with hands-off imperialism, it seems that we need an account of a different kind.

\section{Modally Demanding Values}

My suggestion is that such an account can be had by appreciating that democracy is a very special kind of value - an example of what, following Philip Pettit, I shall 
call a modally demanding value. ${ }^{15}$ I shall begin in this section by briefly discussing this category of values in general.

Many values are modally undemanding. Modally undemanding values are values the instantiation of which depends only on what actually happens. Consider pleasure. Pleasure is a modally undemanding value, since, in order for the value of pleasure to be instantiated, it is enough that people actually have certain phenomenal experience. Or take material equality. Not everyone accepts that material equality is a value at all. But everyone should accept that, if it is a value, it is a modally undemanding value. In order for it to be instantiated, we need only look at whether people are actually equally well off.

Modally demanding values, by contrast, are values the instantiation of which depends not only on what actually happens but also on what would happen - in particular, whether one would continue to enjoy some other value across a range of non-actual circumstances. Philip Pettit has famously argued that freedom is a modally demanding value. ${ }^{16}$ According to Pettit, in order to know whether or not one is free, it is not enough to look at what is actually done to one: say, whether one is coerced, or intentionally interfered with on an arbitrary basis. Consider the slave, surely the paradigmatic example of someone who is unfree. ${ }^{17}$ The slave might be actually coerced or interfered with arbitrarily by his master. Many perhaps most - slaves have unpleasant things actually done to them by their masters. But this needn't be so. Perhaps the slave happens to have an

\footnotetext{
${ }^{15}$ Pettit uses the phrase "modally demanding value" in "Freedom and Probability." In more recent work in progress, Pettit uses the term "robustly demanding values." See Pettit, Making Good.

16 Philip Pettit, Republicanism: A Theory of Freedom and Government (Oxford; New York: Oxford University Press, 1997); A Theory of Freedom: From the Psychology to the Politics of Agency (Oxford; New York: Oxford University Press, 2001); “The Instability of Freedom as NonInterference." See also Quentin Skinner, Liberty Before Liberalism (Cambridge, UK: Cambridge University Press, 1998).

17 Pettit, Republicanism, p. 22.
} 
extraordinarily nice master, who treats the slave well, doesn't put him in chains or whip him when he works too slowly. Perhaps the master even allows the slave to marry, helps to educate his children, and sends him a bottle of vintage Veuve Clicquot every year for his birthday. As far as masters go, he's just about the best one could hope for. Still, the slave is a slave. Part of what this means is that, if the master wanted to, he could do all kinds of unpleasant things to the slave. It is simply not true of the slave that, if his master were less nice, he would not be coerced, or interfered with on an arbitrary basis. ${ }^{18}$ According to Pettit, the example of the slave shows that freedom is a modally demanding value. In order to be free, it is not enough that one actually enjoys the value of non-coercion, or non-interference on an arbitrary basis. Rather, it must be true that one would continue to enjoy the relevant value across a range of non-actual circumstances.

Certain character traits also seem to be modally demanding values. Consider honesty. What does it take in order for an individual to be honest? Clearly it's not enough to know how such an individual actually behaves - say, whether or not she intentionally misleads and deceives others. It may be that she is extraordinarily lucky and simply happens never to encounter circumstances in which intentionally misleading or deceiving others is personally advantageous. Suppose, however, that she is such that, were she to confront circumstances in which even a small personal benefit could be thus obtained, she would show no hesitation to engage in blatant prevarication and deception. It seems clear that it would be a mistake to describe such a person as honest. Honesty is a modally demanding value. To be honest requires that one would continue to behave in

\footnotetext{
18 Ibid., p. 80.
} 
certain ways, such as resisting intentional falsehood and deception, across a range of tempting non-actual circumstances. ${ }^{19}$

Finally, certain personal relationships also seem to be modally demanding values. Consider the value of friendship. What does it take in order for you and me to be friends? Again, it seems that it is not enough to look at what actually happens: whether we actually care for another; whether we actually spend time together; whether we actually display loyalty to one another by, say, refraining from talking about one another behind the other's back; and so on. ${ }^{20}$ Suppose that, as it happens, you are extremely attractive. But, were you to have an accident and lose your good looks, I would cease to care for you. Or suppose that, as it happens, you and I are stuck on a desert island. But, were we to be rescued and return to civilization, neither of us would have any inclination to continue to spend time together. Or suppose that, as it happens, you are extremely rich. But, were you to lose your riches, I would suddenly lose any inhibitions I have about talking about you behind your back. It seems that at least some of these possibilities suffice to show that we are not really friends, or at least not friends of a certain kind. In order for the value of friendship (or at least a certain kind of friendship ${ }^{21}$ ) to be instantiated, it needs to be the case that we would continue to

\footnotetext{
${ }^{19}$ See Henry Sidgwick, The Methods of Ethics (Indianapolis: Hackett Publishing Company, 1981), pp. 220- 222; Gilbert Ryle, The Concept of Mind (London: Hutchinson's University Library, 1949), p. 89; Richard Brandt, "Traits of Character: A Conceptual Analysis," American Philosophical Quarterly, 7 (1970): 23-37, pp. 24-6.

20 I take this example from Pettit, "Making Good."

${ }^{21}$ Plausibly there are different kinds of friendship. And part of what this means is that they are modally demanding across different ranges of non-actual circumstances. For example, take the non-actual circumstance in which one develops chronic depression. Is it a requirement of friendship that one's friend would continue to want to spend time with one if one developed chronic depression? Plausibly it is a requirement of a particular kind of friendship. But there are other kinds of relationships which we may appropriately describe as "friendships" for which it may not be a requirement.
} 
behave in certain valuable ways and have certain valuable attitudes towards one another across a range of non-actual circumstances.

Notice that each of these three values has a certain structure. Corresponding to each value is some valuable modally undemanding (or at least less

demanding) counterpart. The modally undemanding counterpart of freedom is something like non-coercion or non-interference on an arbitrary basis. The modally undemanding counterpart of honesty is something like truth telling. The modally undemanding counterpart of friendship is something like an amalgam of mutual concern, loyalty, and companionship. To instantiate the modally demanding value requires, not only that one actually enjoy its modally undemanding counterpart, but also that one would continue to enjoy its modally undemanding counterpart across a range of non-actual circumstances. ${ }^{22}$

\footnotetext{
22 Notice that modally demanding values must be distinguished, not only from modally undemanding values, but from two other classes of values that also depend on modal considerations. First, they must be distinguished from what I shall call "modally fragile values." A modally fragile value is a value, $\mathrm{V}$, such that, in order for $\mathrm{V}$ to be instantiated by $\mathrm{x}$, there must be some other value, $\mathrm{V}^{*}$, such that $\mathrm{x}$ (or a relevant counterpart of $\mathrm{x}, \mathrm{x}^{*}$ ) would not continue to instantiate $\mathrm{V}^{*}$ across a range of non-actual circumstances, $\mathrm{C}$. The paradigmatic example of a modally fragile value is the value of being lucky. (I am grateful to Al Hajek for this example and for helping me to appreciate the distinction between modally demanding and modally fragile values.) Roughly, one is lucky just in case a) good things actually happen to one and b) these things would not happen to one in relevant non-actual circumstances. For example, escaping paralysis despite sustaining unstable C1 and C2 fractures means that one is lucky in part because it is not true that one would escape paralysis in various non-actual circumstances where one sustained such fractures. Modally fragile values are like modally demanding values in that their instantiation depends, not only on what actually happens, but also on what would happen in certain non-actual circumstances. But, unlike modally demanding values, they involve another value (e.g. the value of having good things happen to one) that one actually enjoys but that one would not enjoy across a range of non-actual circumstances. Second, modally demanding values must also be distinguished from what I shall call "modally pure values." Modally pure values are values whose instantiation depends only on whether some other value would be enjoyed in nonactual circumstances, not on whether it is actually enjoyed. For example, take the value of forbearance. Roughly, one instantiates the quality of forbearance if one would exhibit equanimity in aggravating circumstances. It seems that it needn't be true that one actually ever exhibits equanimity in order to count as possessing the quality of forbearance. Modally demanding values, by contrast, require that their modally undemanding counterpart be actually enjoyed. For example, in order to be free one must actually enjoy the value of non-coercion; this isn't sufficient but it is necessary in order to be free.
} 
It is important to emphasize that, while modally demanding values are modally demanding, there are limits to their modal demandingness. Freedom doesn't require that one would continue to enjoy the value of non-coercion or non-interference on an arbitrary basis if, say some powerful aliens were to arrive and feel like coercing one. With apologies to Kant, honesty doesn't require that one would continue to refrain from intentionally telling lies if, say, one were to confront a murderer looking for the location of his victim. Friendship with another doesn't require that one would continue to care for her if she were to become a serial killer. This point may be formalized as follows. A modally demanding value $\mathrm{V}$ is a value such that V's instantiation requires that there are non-actual circumstances $\mathrm{C}$, such that one would continue to enjoy $\mathrm{V}^{*}$, the modally undemanding counterpart of V, in C. But V's instantiation doesn't require that, for any non-actual circumstance $\mathrm{C}$, one would continue to enjoy $\mathrm{V}^{*}$ in $\mathrm{C}$. Call the latter "infinitely modally demanding values." None of the modally demanding values that I have in mind are infinitely modally demanding. ${ }^{23}$ We might wonder how one is supposed to delineate the relevant range of non-actual circumstances across which particular modally demanding values are modally demanding. It seems to me that to have an understanding of the relevant values just is, in part, to have an understanding of the relevant range of circumstances. ${ }^{24}$ To understand the nature of friendship just is, in part, to understand that it requires mutual concern across changes in attractiveness but not across changes in sanity. If you don't understand this, then you simply lack a grasp of the concept of friendship, or at least you have in mind a very different notion of "friendship."

\footnotetext{
${ }^{23}$ Robert Goodin and Frank Jackson appear to make the mistake of assuming that modally demanding values must be infinitely modally demanding in their article, "Freedom From Fear", Philosophy \& Public Affairs, 35 (2007), 249-65.

24 See also Pettit, "Making Good."
} 
Notice that some of the non-actual circumstances across which modally demanding values are modally demanding may have a very low probability of obtaining. Take friendship. Friendship plausibly requires that the parties to the friendship would continue to exhibit loyalty to one another across changes in income. It may be extremely unlikely that one of the parties, who is a millionaire, will lose his riches. Perhaps he has invested his income extremely judiciously and conservatively in numerous different places. But suppose that, were he to lose his riches, his so-called "friend" would cease to be loyal to him. This is enough in order for friendship, or at least a certain kind of friendship, to be lacking. It doesn't matter that there is a vanishingly low probability that the circumstance in which he loses his riches obtains and hence a vanishingly low probability that his "friend" will cease to be loyal to him. The fact that he wouldn't remain loyal in those circumstances is relevant in and of itself.

It is important to distinguish between the question of what a modally demanding value is and whether it is actually instantiated. I have suggested that character traits such as honesty are modally demanding values. I also happen to think that they are sometimes actually instantiated; that is, I think there are some honest people. But notice that one might accept the first claim and deny the second claim. Indeed, that's precisely what a number of philosophers influenced by situationism urge. ${ }^{25}$ According to the situationists, our actions and attitudes are massively affected by the particular circumstances in which we happen to find ourselves, to the point where it is simply not true that we would continue to be truthful and avoid deceiving others in less pleasant circumstances. From this

\footnotetext{
${ }^{25}$ See Gilbert Harman, "Moral Philosophy Meets Social Psychology: Virtue Ethics and the Fundamental Attribution Error," Proceedings of the Aristotelian Society, 99 (1999): 315-31; and John Doris, Lack of Character: Personality and Moral Behavior (Cambridge, UK; New York: Cambridge University Press, 2002).
} 
the situationists infer that we lack character traits such as honesty. Notice, however, that this doesn't undermine the claim that character traits such as honesty are modally demanding values. Indeed, the situationist critique crucially depends on holding that character traits are modally demanding. It is in part because character traits are modally demanding that we are unable to satisfy the conditions required in order for them to be instantiated.

Finally, I have said that modally demanding values have modally undemanding counterparts that are also themselves valuable; and clearly the value of modally demanding values derives in part - perhaps even in large part from the value of their modally undemanding counterparts. ${ }^{26}$ However, I take it to be an important feature of modally demanding values that their value is not wholly reducible to the value of their modally undemanding counterparts. This isn't to say that modally demanding properties aren't fully metaphysically reducible - e.g. to certain complex categorical properties. I take no stand on the question of the ontological fundamentality of modally demanding properties. Again, it isn't to say that the value of modally demanding values isn't fully reducible to some other modally undemanding value(s). I take no stand on the question of whether modally demanding values are intrinsic values. The point is just that the value of modally demanding values is not reducible specifically to the value of their particular modally undemanding counterpart. Suppose that I know that I will never be actually coerced or subject to arbitrary interference. Does it follow that I have no additional reason to want to be such that I would

\footnotetext{
26 Thus, an important part of why we have reason to want to be free is that we have reason to want to avoid coercion, or interference on an arbitrary basis. An important part of why we have reason to want people to be honest is that we want them to tell the truth. And an important part of why we have reason to want to have friends is that we want to have relations of mutual concern, companionship, and loyalty.
} 
continue not to be coerced or interfered with on an arbitrary basis? Surely not. My situation is consistent with being a slave. I may know that my master will never coerce me or interfere with me arbitrarily. Yet I may surely wish for my freedom. I may wish to be such that I am no one's slave, not to be dependent on any individual's continued good-will. Or suppose that I know that, as a matter of fact, my child is never going to face a situation in which it will be personally advantageous for her to lie, but that, were she to face such a situation, she'd lie with impunity. Does this mean that I have no additional reason to want her to be such that she would continue to refrain from lying in such circumstances? Surely not. I may care about the quality of her charcter. Or suppose that I know that a particular individual of my acquaintance will always, as a matter of fact, have concern for me, wish to participate in shared activities, and not talk about me behind my back. Does this mean that I have no additional reason to care about whether the individual in question would continue to have concern for me, wish to participate in shared activities, and not talk about me behind your back if, say, I were to become less rich or attractive? Surely not. I may care about the quality of the relationship that we enjoy.

We might wonder why this should be? In the case of freedom, it seems to me that we have reason to care about having a certain kind of status. In the case of honesty, it seems to me that we have reason to care about being certain kinds of people. And in the case of friendship, it seems that we have reason to care about being in certain kinds of relationships. Perhaps these are valuable in their own right. Alternatively, perhaps they are valuable only because they are necessary in order to realize certain other (perhaps modally undemanding) values: to have certain kinds of valuable experiences, say. In any case, the value of modally 
demanding values such as freedom, honesty, and friendship goes beyond their modally undemanding counterparts in an important way.

So much for modally demanding values in general. I shall now suggest that we should also understand democracy in particular as a modally demanding value.

\section{Self-Rule as a Modally Demanding Value}

Here is one possible view of democracy. Democracy requires only collective selfgovernance. By "collective self-governance" I mean the idea that the decisions of the collective are actually determined by the will of the members of the collective. There are numerous different views about what this amounts to precisely: whether the people must make the decisions themselves, ${ }^{27}$ or whether their representatives should do so on their behalf; ${ }^{28}$ whether the decisionmaking procedures involve aggregating the unconsidered views of the people, ${ }^{29}$ or whether the views must be submitted to deliberative scrutiny; ${ }^{30}$ which individuals count as members of the collective; ${ }^{31}$ and so on. These issues, while of the first importance, don't matter for my purposes here. What does matter is that it is enough, in order for a polity to be said to govern itself, that the polity

\footnotetext{
27 See Carole Pateman, Participation and Democratic Theory (Cambridge, UK; Cambridge University Press, 1970).

${ }^{28}$ See Nadia Urbinati, Representative Democracy: Principles and Genealogy (Chicago: University of Chicago Press, 2006).

${ }^{29}$ See Robert Dahl, Democracy and Its Critics (New Haven: Yale University Press, 1989).

30 See Amy Gutmann and Dennis Thompson, Democracy and Disagreement (Cambridge, Mass.: Belknap Press of Harvard University Press, 1996); John Dryzek, Deliberative Democracy and Beyond: Liberals, Critics, Contestations (Oxford; New York: Oxford University Press, 2000). 31 See Claudio Lopez-Guerra, "Should Expatriates Vote?" The Journal of Political Philosophy, 13 (2005): 216-34; Francis Schrag, "The Child's Status in the Democratic State," Political Theory, 3 (1975), 441-57; Christian List and Mathias Koenig-Archibugi, "Can There Be a Global Demos? An Agency-Based Approach,” Philosophy \& Public Affairs, 38 (2010): 76-110.
} 
makes decisions that are actually determined (in the relevant way) by the will of the people.

I want to put forward a different view of democracy. According to this alternative view, democracy requires something more than collective selfgovernance. It requires what I shall call collective "self-rule." 32 In order for a polity to rule (as opposed to govern) itself, it is not enough that the will of the people actually determines the decisions of the polity. Rather, the polity must be such that the will of the people would continue to determine the decisions of the polity across a range of possible situations. Self-rule is thus the modally demanding (or perhaps modally more demanding ${ }^{33}$ ) counterpart of selfgovernance; it involves robust self-governance.

Which counterfactuals must be true in order for there to be self-rule? I suggest that self-rule involves at least two kinds of counterfactual requirements. First, the polity must be such that the will of the people would continue to determine the decisions of the polity across certain changes in the content of the will of the person or persons who occupy the position of highest authority in the polity. Call this the "First Counterfactual Requirement." Consider Monarcho, which is subject to an absolute monarch. The executive power of the monarch in Monarcho is unrestricted. There are no constitutional checks and balances. The secret police and army are there at his beck and call, and will do whatever is

\footnotetext{
32 Some might take issue with the claim that democracy "requires" self-rule, on the grounds that democracy is something that comes in degrees. Perhaps I should instead say that the presence of self-rule makes a polity more democratic and, hence, that the extent to which a polity is democratic is determined not merely by the extent of self-governance. While I shall continue to speak in what follows of self-rule as a necessary condition of democracy, I would be happy to speak instead of self-rule as a determinant in the degree to which democracy is instantiated in a polity. I am grateful to Leif Wenar for forcing me to clarify this point.

33 Plausibly, the idea of the will of the people "determining" a decision is already a modally demanding notion. If this is right, then even self-governance is modally demanding in an important sense.
} 
required to execute his wishes. As it happens, the absolute monarch of Monarcho is extremely apolitical, and prefers to spend his days in his harem and to leave the business of governing Monarcho to his brothers. The brothers, who are big fans of Thomas Paine and John Stuart Mill, set about implementing systems of governance that have the aim of ensuring that political decisions are determined by the will of the people of Monarcho. Elections are held, representatives are elected, coffee houses and salons proliferate. The people of Monarcho become politically informed and engaged, and participate in the governance of Monarcho to an extent never before seen in their history. But while there is self-governance in Monarcho, there is not self-rule. For it is not true that the will of the people would continue to determine the decisions of Monarcho if the will of the monarch were to change. The monarch could clamp down on the citizens of Monarcho at any stage if he wanted to. As it happens, he shows no inclination to budge from his harem, and the self-governance of Monarcho by the people continues unabated; the Monarchians are justified in being extremely confident that this will continue. However, the monarch has only to make a call to the secret police and army, and the patrons of the coffee-houses and salons will be summarily executed, and the elected representatives of the people thrown into prison and tortured. The First Counterfactual Requirement is therefore not met by Monarcho. Self-governance in Monarcho is not modally robust. There is selfgovernance but not self-rule.

What would be necessary in order for the First Counterfactual Requirement to be met in Monarcho? At the very least, Monarcho would have to become a constitutional monarchy. Unlike absolute monarchy, constitutional monarchy involves placing tight constitutional constraints on the power of the monarch. 
Within a constitutional monarchy, the maintenance of self-governance is not dependent on the will of the monarch. Alternatively, the Monarchians could overthrow the absolute monarch and transform Monarcho into a democratic republic. Within a democratic republic, the highest authority is held by the people (or at least some significant portion of them). The First Counterfactual Requirement is therefore trivially satisfied in the case of a democratic republic, since there is no discrepancy between the people and the person or persons who wield supreme authority. A change in the will of the persons wielding authority just is a change in the will of the people.

It is important that we don't confuse the First Counterfactual Requirement with the following false counterfactual requirement: that the polity must be such that the will of the people would continue to determine the decisions of the polity across certain changes in the content of the will of any powerful agent either within or outside the polity. Plausibly, this counterfactual requirement is not met by many actual democracies. Take New Zealand. Presumably there are polities, such as the US and China, that are powerful enough that, if they really wanted to undermine self-governance in New Zealand, they could do so. Perhaps there are even certain individuals, such as Bill Gates, who could undermine selfgovernance in New Zealand if they so chose. So it is not true of New Zealand that the will of the New Zealand people would continue to determine the decisions across certain changes in the content of the will of the US or Bill Gates. Still, intuitively this doesn't undermine self-rule in New Zealand. At most, it shows that self-rule in New Zealand is not itself modally robust across certain nonactual circumstances. Perhaps this is something to be deplored; perhaps we have reason to want self-rule to be modally robust across certain possible changes in 
the will of powerful agents. But the claim I am making is a different one, namely, a claim about what self-rule itself amounts to. And self-rule does not require that self-rule itself be modally robust. Rather, it requires that self-governance be modally robust.

Still, it might seem that the First Counterfactual Requirement is too strong. Consider federalist polities, where the national government, the highest authority, is able to override legislation passed by states. The First Counterfactual Requirement seems to have the odd consequence that self-rule is impossible at the level of states within federalist polities. This objection rests on a mistake. It is a crucial feature of federalist polities that states are authoritative with respect to certain classes of political decisions (secondary education, say), and that decisions within the relevant class may not be overridden by the national government. What this means is that states satisfy the First Counterfactual Requirement with respect to these decisions. Of course, there are other decisions with respect to which the national government can override state legislation. But the right thing to say seems to be that states do not enjoy selfrule with respect to these other decisions. ${ }^{34}$

So much for the First Counterfactual Requirement. But there is another counterfactual that must also be true of a polity in order for there to be self-rule. The polity must also be such that the will of the people would continue to determine the decisions of the polity across certain changes in the content of the will of the people. Call this "the Second Counterfactual Requirement." Consider Totalitaria, a totalitarian state where the highest authority is the Party. Initially, the Party itself governs Totalitaria. However, authoritarian rule has been so

\footnotetext{
${ }^{34}$ I am grateful to Dave Wiens for discussion of cases of this kind.
} 
effective in Totalitaria that the people of Totalitaria have come to believe that Totalitarianism is the best form of government and to fully internalize the will of the Party. The Party therefore deems the people of Totalitaria "ready" to participate in the governance of Totalitaria. Elections are held and representatives elected. The political decisions taken by Totalitaria are determined by the will of the people of Totalitaria, which corresponds perfectly to the will of the Party. The people decide to continue to require parents to give up their children to be "educated" by the Totalitarian state, to have an extensive secret police that submits the people to constant surveillance, to invade states who don't share the values of Totalitaria, and so on. Nonetheless, again, while there is self-governance in Totalitaria, there is not self-rule. For the Second Counterfactual Requirement is not met in Totalitaria. It is not true that the will of the people would continue to determine the decisions of Totalitaria if the will of the people were to change so as to be out of sync with the will of the Party. Were the citizens of Totalitaria to acquire opinions that were at odds with the will of the Party, the Party would automatically destroy the new institutional apparatus, cancel elections, and reclaim responsibility for the governance of Totalitaria. To be sure, this may be very unlikely, given how effective the indoctrination in Totalitaria has been. Still, the Second Counterfactual Requirement is not met in Totalitaria. Self-governance in Totalitaria is not robust. Therefore, there is not self-rule.

Again, it is important that we don't interpret the second counterfactual in such a way as to make it too modally demanding. It surely isn't true that in order for there to be self-rule in a polity, the polity must be such that the will of the people would continue to determine the decisions of the polity across any 
changes in the content of the will of the people. Rather, there are certain contentbased restrictions that are perfectly consistent with (and arguably required by) the notion of self-rule. Consider, first, the possible situation where the people become radical anti-democrats. If the will of the people were to determine the decisions of the polity in this situation, the decision would be to get rid of democracy. This is not required - and is probably not even permitted - by the idea of self-rule. ${ }^{35}$ Second, consider the possible situation where the people become incredibly nasty and wish to run roughshod over the rights of a particular minority: to deprive them of their civil rights and encourage active discrimination. Again, if the will of the people were to determine the decisions of the polity in this situation, the decisions would be anti-democratic, at least if democracy is interpreted in a "thick" sense to include certain rights. Self-rule needn't require (or even permit) that self-governance be modally robust in these ways.

I have suggested that self-rule (and therefore democracy) is modally demanding in two important respects. But is self-rule a modally demanding value? Modally demanding values, as we saw, are more than modally demanding phenomena that are valuable. Rather, they are valuable modally demanding phenomena whose value is not reducible to the value of their modally undemanding counterparts. The modally undemanding counterpart of self-rule is self-governance. Is the value of self-rule reducible to the value of selfgovernance?

\footnotetext{
35 See Gerhard Overland and Christian Barry, "Do Democratic Societies have a Right to do Wrong?" Journal of Social Philosophy, 42 (2011): 111-31.
} 
Clearly the value of self-rule derives in part - perhaps in large part - from the value of self-governance. Self-governance is plausibly something we have reason to want, perhaps for own sake, but certainly at least because it helps us to realize certain other moral, epistemic, and prudential values. Still, I think there is a compelling intuitive case for thinking that the value of self-rule isn't reducible to the value of self-governance, that something of normative importance is added when we move from self-governance to self-rule. ${ }^{36}$ It would be hard otherwise to make sense of the claim that the people of Monarcho have reason to overthrow the absolute monarch, and the claim that the people of Totalitaria have reason to overthrow the Party. The people of Monarcho and Totalitaria already govern themselves. What is lacking in Monarcho and Totalitaria is self-rule, that is, a form of self-governance that is modally robust. ${ }^{37}$

Can we say something to explain and justify this intuitive case? There are various possibilities. One possibility is that the modally demanding character of self-rule is normatively important because it gives us a certain kind of valuable status. This is the kind of suggestion that I made in the context of trying to explain and justify the importance of the modally demanding character of freedom. Slaves have reason to want to enjoy robust non-coercion or noninterference on an arbitrary basis, even if they know that they are virtually certain not to be actually coerced or interfered with on an arbitrary basis,

\footnotetext{
${ }^{36}$ I make no claim here about the comparative value of self-rule and self-governance. Certainly I don't want to deny that there are cases where it makes sense to sacrifice self-rule in the interests of preserving self-governance. My claim is the relatively weak one that the value of self-rule isn't reducible to the value of self-governance.

37 Notice that if my claim that the value of self-rule isn't reducible to the value of self-governance is correct, this casts doubt on accounts that explicate the value of democracy in purely epistemic terms, since the epistemic value of self-rule is presumably derived wholly from the epistemic value of self-governance. However, the claim is consistent with more nuanced epistemic accounts, such as the form of epistemic proceduralism defended by David Estlund in Democratic Authority: A Philosophical Framework (Princeton, N.J.: Princeton University Press, 2008).
} 
because this is necessary in order for them to enjoy a certain kind of valuable status. Similarly, it might be said that there is a kind of valuable status that depends on enjoying robust self-governance, a kind of status that subjects of an absolute monarchy or totalitarian society inevitably lack, even if they happen to enjoy the value of self-governance. ${ }^{38}$

A second possibility is that it is important to our sense of identity, who we are. We care about whether we and others are certain kinds of individual persons. For example, we care about whether individuals are honest, trustworthy, and self-sufficient. I suggested that the modally demanding character of these qualities is normatively important because it concerns the kinds of people we are. Plausibly, we also care about being certain kinds of collective persons. Perhaps the importance of self-rule, as opposed to mere selfgovernance, derives in part from what it tells us about the "personality" of the collective person that is the polity. We have reason to want to be part of a polity that has a certain kind of independence and self-sufficiency. Self-governance doesn't deliver that, whereas self-rule does.

Finally, perhaps the modal demandingness of self-rule is important because of what it implies for the kind of relationship that citizens stand in with respect to one another. I suggested that the modal demandingness of friendship makes it a relevantly different kind of relationship from one in which individuals just happen to care for, and desire to spend time with, one another. Similarly, perhaps it will be said that for us to be co-self-rulers (as opposed to mere co-self-

\footnotetext{
38 See Thomas Christiano, The Constitution of Equality: Democratic Authority and its Limits (Oxford; New York: Oxford University Press, 2008).
} 
governors) is thereby to enjoy a special kind of relationship with one another: a relationship of mutual authority and accountability. ${ }^{39}$

Each of these proposals seems to me to have some merit. Indeed, they are not mutually exclusive, so we don't need to choose between them.

\section{Solving the Problem of Hands-Off Imperialism}

Imperialism seems to be deeply antithetical to democracy. Yet, as we saw, imperialism can be hands-off as well as hands-on. Whereas the democratic case against hands-on imperialism is relatively straightforward, the question of what is supposed to be democratically objectionable about hands-off imperialism is more mysterious, since hands-off imperialism seems to be perfectly compatible with self-governance.

We are now in a position to resolve the mystery. The key is that democracy involves more than self-governance. Rather, it involves self-rule, which is the modally demanding counterpart of self-governance. There are two kinds of counterfactual requirements that must be met by a polity in order for it to instantiate the value of self-rule and hence be a democracy. First, the polity must be such that the will of the people would continue to determine the decisions of the polity across certain changes in the content of the will of the person or persons who occupy the position of highest authority in the polity. Second, the polity must be such that the will of the people would continue to determine the

\footnotetext{
39 See Joshua Cohen, "Procedure and Substance in Deliberative Democracy," in James Bohman and William Rehg (eds), Deliberative Democracy: Essays on Reason and Politics (Cambridge, Mass.: MIT Press, 1997): 407-37; Seyla Benhabib, Democracy and Difference (Princeton, N.J.: Princeton University Press, 1996); and Nicholas Southwood, Contractualism and the Foundations of Morality (Oxford: Oxford University Press, 2010), ch. 5.
} 
decisions of the polity across certain changes in the content of the will of the people.

Imperialism, even in its hands-off guise, violates both counterfactual requirements. It violates the First Counterfactual Requirement because, even if the imperial power chooses not to take over the governance of the occupied polity, the fact remains that it could do so if it changed its mind. Return again to Pacifistia. The president of Pugnatia may be perfectly happy to allow the Pacifistians to govern themselves. Moreover, the Pacifistians may be perfectly justified in being virtually certain that this will continue. Still, were the president of Pugnatia to change his mind and come to desire to govern Pacifistia himself, he could do so. Therefore, it is not true of Pacifistia that the will of the Pacifistians would continue to determine the decisions of the Pacifistian polity across such changes in the content of the will of the president of Pugnatia.

Hands-off imperialism also violates the Second Counterfactual Requirement. Even if the people of the occupied polity happen to support the continued occupation of their polity, and hence the political decisions that are reached happen to be determined by the will of the people, the will of the people could be different. For example, the Pacifistians might, as a matter of fact, be perfectly reconciled to occupation by Pugnatia. Yet it remains true that if the Pacifistians were to change their mind and decide to expel the Pugnatians, then the continued occupation would not be compatible with meaningful self-governance in Pacifistia. Even if the rulers of Pugnatia are happy to allow the Pacifistians to make such a decision, they cannot allow them to carry it out without, in effect, ending their imperial rule. So it is not true of Pacifistia that the will of the 
Pacifistians would continue to determine the decisions of the Pacifistian polity across such changes in the content of the will of the Pacifistians.

We therefore have a straightforward explanation for why there is necessarily something democratically objectionable about imperialism. Imperialism is necessarily democratically objectionable, because democracy involves self-rule, and imperialism violates two fundamental requirements of self-rule.

Notice that this explanation represents an improvement on the three alternative explanations we considered above. The increased probability account held that the democratic case against hands-off imperialism is that the occupation and control of one polity by another polity will increase the probability that self-government in that polity will be undermined. As we saw, that needn't be so, if, say, there is another state, Fascistia, that is very likely to occupy Pacifistia if Pugnatia doesn't do so and very likely, if it does so, to undermine self-governance in Pacifistia. So the increased probability argument fails to explain what is democratically objectionable about imperialism in this case. The thing to note is that, even if occupation of Pacifistia by Pugnatia lowers the probability that self-governance will be undermined, it remains inconsistent with self-rule in Pacifistia, since it violates the First Counterfactual Requirement. By contrast, the mere fact that Fascistia is hovering ready to pounce is perfectly compatible with the First Counterfactual Requirement. Of course, the presence of Fascistia presumably makes it the case that self-rule in Pacifistia is rather modally fragile. But democracy does not entail modally robust self-rule. Rather, it only entails modally robust self-governance. 
Next, the practical impossibility account held that the democratic case against hands-off imperialism is that hands-off imperialism makes selfgovernance within the occupied polity practically impossible. As we saw, this needn't be so, if, say, the citizens of Pacifistia become reconciled to imperial rule by Pugnatia. Again, the practical impossibility account fails to explain what is democratically objectionable about imperialism in this case. However, even if the people are, as a matter of fact, reconciled to imperial rule by Pugnatia, it remains inconsistent with self-rule in Pacifistia, since it violates the Second Counterfactual Requirement.

Finally, the rights account held that the democratic case against hands-off imperialism is that hands-off imperialism involves the violation of rights that are part of part of democracy, interpreted in a "thick" sense. I suggested that handsoff imperialism needn't violate those rights that are plausible candidates for being included in a thick interpretation of democracy, if, say, Pugnatia has become so powerful that it can afford to allow the Pacifistians to express views hostile to Pugnatia, to form organized resistance groups, and so on. Yet even if this happens to be true, self-rule is undermined, since both counterfactual requirements are violated. It is perhaps worth adding that a proponent of a "thick" interpretation of democracy might insist that democracy requires that respect for rights that are partially constitutive of democracy also be modally robust across changes in, say, the power of the occupying polity. If this is right, then we have yet another democratic reason to object to imperialism. 